\title{
Enhancing Intercultural Communication and Understanding: Team Translation Project as a Student Engagement Learning Approach
}

\author{
Ping Yang ${ }^{1}$ \\ ${ }^{1}$ School of Humanities and Communication Arts, University of Western Sydney, Australia \\ Corrspondence: Ping Yang, School of School of Humanities and Communication Arts, University of Western \\ Sydney, Locked Bag 1797, Penrith, NSW 2751, Australia. Tel: 61-2-9772-6514. E-mail: p.yang@uws.edu.au
}

Received: February 8, 2015 Accepted: March 31, 2015 Online Published: July 27, 2015

doi:10.5539/ies.v8n8p67 URL: http://dx.doi.org/10.5539/ies.v8n8p67

\begin{abstract}
This paper reflects on a team translation project on Aboriginal culture designed to enhance university students' intercultural communication competence and understanding through engaging in an interactive team translation project funded by the Australia-China Council. A selected group of Chinese speaking translation students participated in the project and two English books on Australian Aboriginal history and culture were translated to Chinese from August 2011 to May 2012. The two bilingual books were published by Aboriginal Studies Press in May 2013. After the one-year translation project was completed, the author conducted a survey and audio-taped interviews about the participants' translation experience. Using social constructivist theory (SCT), the author coded the data, conducted critical analysis of the contents, and categorised the themes. It was found that the participants not only improved their translation skills through combining theories with practices, but also got better knowledge of Australian Aboriginal cultural tradition and history than before. Having understood cross-linguistic differences, they combined translation theory with practice and raised their intercultural awareness after going through various organized learning activities centring on the translation project. Such an interaction-based student engagement learning approach helped student translators achieve meaningful communication and learner autonomy through individual reflections, group discussions, and seminars. Finally the pedagogical implications of the team translation project were discussed.
\end{abstract}

Keywords: intercultural communication competence, Australian aboriginal culture, student engagement learning, English-Chinese translation

\section{Introduction}

Formal translation training as part of university translation degree programs is often delivered in the classroom although translation practicum or internship is an exception. Students may be given some short translation assignments to complete in or after class and the assignment topics are of different kinds. As they usually translate extracts without sufficient context or authentic materials (Grim, 2010), particularly those with well-selected culture-loaded information, it is likely that they do not feel engaged in doing the translation exercises. Apparently a student engagement learning approach (Sellnow \& Ahlfeldt, 2005; Turner, 2009) to translation is expected. Furthermore, little research has been conducted on how such an alternative approach to traditional teacher-centred classroom instructions works to improve students' translation skills and raise their intercultural communication awareness (Pym, 2004). As will be discussed below, the findings of the team translation project show that student engagement learning approach used focuses on interactive learning (Diochon \& Cameron, 2001), which is often used in teaching English as a second/foreign language, and features exploratory and reflective learning, critical thinking, meaningful communication and team collaboration.

The author will first review relevant literature and briefly describe the team translation project. Second, research methodology used will be described, including participants, data collection and analysis. Third, the author will focus on detailed discussion of three learning activities designed for participants to develop a better understanding of Australian Aboriginal history and culture and improve their translation skills. Finally the author will discuss the pedagogical implications of the team translation project.

\section{Literature review}

In this section, literature review focuses on team work on translation project and on developing students' 
intercultural communication competence through translating linguistic differences, enhancing intercultural understanding through task-based translation and student engagement learning approach.

\subsection{Translating as Communicating Linguistic Differences}

While the world is becoming more globalized, intercultural communication has increased and has seen people from different linguistic and cultural background interacting with one another more frequently than ever before, such as engaging in international business activities, travelling to popular holiday destinations and studying, for example, translation in an overseas higher education institution, particularly an English-speaking university. To communicate successfully with the people in a language other than one's mother tongue and survive in a new host culture, intercultural communicators need to have decent intercultural competence whose importance has been recognized by international employers, educators and researchers across the world. Starke-Meyerring (2005, p. 54) maintains that effective professional communication in intercultural context requires that professional communicators develop global communication literacies, knowing selves and others as well, especially those from different cultural groups. Mughan (1999) points out that the foreign language programs designed need to accommodate the needs of foreign language learners, and their course materials will assist effective student learning if developed with intercultural sensitivity. Then it is necessary for translation students to understand that awareness of linguistic differences is one of the key elements of intercultural communication competence.

Translation involves written communication from a source language (SL) to a target language (TL) through decoding and encoding linguistic symbols. As there are linguistic differences (e.g. semantically and pragmatically at lexical, syntactic and discourse levels) between an SL and a TL, translation students need to observe these differences and ensure ambiguities are eliminated at the said levels. For example, let us have a look at linguistic differences observed in the Chinese translation of the following English sentences.

Example 1: "Terrorists have ambitions of empire, warns Cheney (Note 1)."

(“契尼提醒人们: 恐怖分子有野心建立帝国”)

Example 2. "Boundless ambition.(Note 2)": This report describes Gavin Lockley, a 29-year-old Australian and currently a PhD candidate in music at Oxford University, has a big dream to create Symphony Of Australia, "an ambitious six-part composition" of music, word and song about Australian stories.

(雄心无限: 本文描述了一位 29 岁的澳大利亚人盖文.洛克理, 他现在牛津大学攻读音乐博士, 抱负远大, 怀有遂愿去创作一部《澳大利亚交响乐》, 共有六个乐章, 以音乐、文字和歌曲诉说澳大利亚的故事。)

Comparing the above two examples, we can see that the English word "ambition" has an inclusive and implicit connotation in English, projecting a derogatory sense in Example 1 but a complimentary sense in Example 2. Whether "ambition" is rendered derogatory or complimentary in translation depends on the context and theme under discussion. It is observed that the Chinese translation of "ambition" in the two examples given above is representative of the Chinese language and cultural values which make the speaker's or writer's position explicit. Adding to Sorby's (2008) point that either derogatory or complimentary meaning applies to Chinese news reports, Yang (2012) finds that three dimensional derogatory-medium-complimentary continuum can be applied to English-Chinese translation in context, for example, “ambition" (野心-追求-雄心) and "be killed" (被击皆死去-牺牲). The derogatory and complimentary connotations in Examples 1 and 2 are not semantically shared by one word in Chinese as it is the case with the English word "ambition", but two words which have contrasting meaning, one for derogatory sense (e.g. 野心) and the other for complimentary sense (抱负远大). In this case, Chinese wordings used in translation of English tend to be more closed-ended context-free while English wordings can be regarded more opened-ended and context-dependent. What is semantically accepted in SL and SC may not be pragmatically accepted in TL and TC due to different communication styles, diverse social practices, and cultural values.

When students are translating these linguistic differences, they are also translating cultural differences embedded in the SL. As both House $(2009$, p. 7) and Pym $(2004$, p. 7) put it, the nature of translation is a matter of intercultural communication, in which translators make sense of both SL and TL as well as source culture (SC) and target culture (TC). Pym (2004) considers localization as a successful and appropriate translation model in adapting to the needs of the target readers. While emphasizing the role of cross-cultural communication, he dwells upon the translation conducive to language learning as well, indicating what he calls "passive language competence" (p.7). In order to develop the intercultural competence of foreign language learners, educators advocate that drama has a unique role to play in offering them many opportunities to experience various aspects (e.g. emotions, attitudes and identities) of SL and SC within a foreign language classroom through learning intercultural knowledge in context and participating in communication (Cunico, 2005). Thus translating 
intercultural differences is challenging, but important and educational.

\subsection{Translating as Communicating Intercultural Differences}

One of the challenges facing translators is decoding various intercultural differences (social, cultural, cognitive, etc.) hidden in the SL and encoding them in TL intelligible to target readers. Alptekin (2002) makes a point that both native and non-native speakers need to have intercultural literacy and communication competence due to more non-native English speakers than native English speakers. This competence shows translators' willingness to communicate interculturally and their attitude to approach cultural diversity.

Challenging as it is, translating cultural differences proves to be thought-provoking and educational in advertising. Translating English advertising texts into French is an exciting job and making intercultural differences understood in translation can help consumers accept culture-specific information in the TL and thus is essential in a successful advertising campaign (Adab, 2000). Adab (2000, p. 201, 202) considers the translation of "Rolex and Omega" and "Kelloggs" as culturally inappropriate in their advertising wordings. Even if advertising designers and market professionals try their best to make their products marketable and appealing physically and technically, they find it beyond their ability to avoid injecting into them their own cultural norms and practice in terms of linguistic description, images and behaviour. Yang (2011b) examines how an Australian tourism advertising "Where the bloody hell are you?" failed to attract overseas tourists and instead evoked many negative responses and even criticism from other English speaking countries as well. For example, "the American Family Association (AFA), ..., was upset with the bikini-clad model Lara Bingle's use of 'bloody' and 'hell' in the ad's tagline" (Note 3). For another example, Canadian regulators banned the drinking of unbranded beer scene in the same ad and the word "hell" was considered inappropriate for children (Note 4). More disappointingly, it does not make any good sense when literally translated into some of Asian languages (e.g. Chinese, Japanese, Korean and Thai etc.,) and these speakers of different linguistic and cultural backgrounds feel the rudeness and hostility instead. What is intended as a humorous and fun message in an Australian cultural script "bloody" (Wierzbicka, 2002), however, is lost in translation to Asian tourists who take the mildest of expletives as sternly impolite, thus contributing to make Australian visitation numbers flat. In a similar vein, Woodward-Smith and Eynullaeva's (2009) cross-cultural study of the translation and adaptation of advertisements for beauty products highlights the point that one-size-fits-all advertising strategies need to be changed to accommodate the culturally diverse markets, and they find "localization" and "adaptation" (p. 123) translation a useful and practical solution to culture-specific issues.

Increased experience translating cross-cultural differences can apparently help develop translators' intercultural communication competence, enabling them to reflect on culturally appropriate translation fit for target readers. Pym (2004) claims that "the greater the complexity of cross-cultural communication, the greater the power of professional intercultures" (p. 20) who "may progressively lose secondariness, extend themselves socially, and become primary cultures" (p. 21). This sees their intercultural communication competence reach its climax so that "the interplay of acculturation and deculturation" tends to lead to assimilation (Kim, 2003, p. 245). No matter whether intercultural contact occurs in real social interaction or in translation assignments, processing intercultural information flow is more than mechanical transfer and it requires that translators use their prior knowledge, interpret cultural concepts appropriately and contrast intercultural differences before they are likely to produce translated texts that are meaningful to the target readers.

It is essential that translation professionals have sound cross-linguistic competence and cross-cultural competence (Muńoz-Calvo, 2010). It is equally important that translation graduates and students work to develop these competences and keep updating their linguistic knowledge and cultural literacy so that they are able to cope with the diverse subject matters to be translated, hence the importance of professional development (Yang, 2011a). Understanding that this is a must-do in the third-year undergraduate unit Intercultural Communication the author coordinates and teaches at UWS, a wide range of intercultural communication topics are covered during a period of thirteen semester weeks. The scheduled lectures supplanted with YouTube and video materials keep translation students well informed of intercultural communication theories and developments. Additionally, student-centred tutorials provide them with opportunities to engage in peer/group discussions and individual/group presentations. Those who participate in the translation project find it more comfortable and confident to analyse the cultural information-packed texts thoughtfully and translate the given book sections appropriately. More will be discussed in Section V.

\subsection{Student Engagement in Learning}

Student engagement in learning is characterised by students participating in various learning activities, developing reflective learning and analytical capabilities, and enhancing meaningful communication (spoken and 
written) skills. Participation in learning activities outside the classroom boundary provides learners an opportunity to experience a variety of authentic life events and expand their visions (Grim, 2010). While they use exploratory practice, their learning autonomy grows. This sees them become more responsible for their own learning and make their own learning decision (Chu, 2007; Little, 2009). In this way, learners learn out of self motivation as they feel interested in learning what is useful and relevant to their current university coursework and future career.

In addition, active participation and careful observation help learners connect textbook knowledge to their real life experience, finding what they are learning authentic. With teachers providing learning guide and support, learners undertake reflective thinking, integrating their prior international learning experience, style and contents with the local ones in order to achieve better intercultural learning outcomes (Turner, 2009). Such a reflective learning process features learners' use of critical thinking and analysis being developed via classroom-based learning activities like individual/pair presentations or other forms of public speaking (Sellnow \& Ahlfeldt, 2005). Development of reflective learning and critical thinking skills is more likely to enable learners to become creative and forward thinking-oriented in teamwork.

Finally, student engagement in learning greatly benefits students in that they learn and develop functional and meaningful communication skills when they are engaged in discussing issues in a team environment. Not only are they willing to communicate in English as a second language (ESL), they also become confident to do so in spite of many factors involved (Cao \& Philp, 2006). Such individual experience, in turn, works to motivate students to compare linguistic differences between L1 and L2, reflect on cultural diversity, communicate across cultural boundary, make friends, develop intercultural sensitivity and adaptation, and feel more confident and competent in a host culture.

\section{The ACC-Funded Translation Project}

The translation project "Understanding Australian Aboriginal Culture through Translation" was financially funded by The Commonwealth through the Australia-China Council of the Department of Foreign Affairs and Trade (2011-2012). Consistent with the goals of Australia-China Council (ACC), this project aims to increase awareness and understanding in China of Australian society and culture, particularly Australian Aboriginal history and cultural heritage through translating into Chinese Aboriginal Sydney: A Guide to Important Places of the Past and Present (2010, $2^{\text {nd }}$ ed.) (hence Aboriginal Sydney) and Aboriginal Darwin: A Guide to Exploring Important Sites of the Past \& Present (2006) (hence Aboriginal Darwin). Both books are written for tourists giving them tour information about Sydney and Darwin from the perspectives of the Australian Aboriginal people and combining site information with Aboriginal history and culture.

In May 2013, Aboriginal Sydney and Aboriginal Darwin were published in bilingual version (Chinese and English) by Aboriginal Studies Press. The two bilingual books will not only give a broader Chinese speaking community an opportunity to get to know about Australian Aboriginal history and culture, but also add to language learning resources for Chinese speakers learning English as a foreign (second) language, and for English speakers learning Chinese as a foreign (second) language as well.

\section{Research Methodology}

According to social constructivist theory (SCT) developed by Vygotsky (1978), our knowledge and skills come from our careful observation, experiments, practice and social interaction with other people. This provides us with an opportunity to learn with our own eyes, via a range of channels and through engaging in various meaningful and collaborative communication activities, thus making autonomous learning relevant, dynamic, and constructive. SCT allows the researcher to engage in down-to-earth work by vigorously examining the data with attention to relevant details and building meaningful connection between key themes from them. This sees knowledge constructed out of a meaningful context in which active situated learning occurs rather than making groundless assumptions.

Ten people including three staff members and seven students participated in the translation project. The staff members had teaching experience in English-Chinese and Chinese-English translation and/or research experience. Students who were involved in the project either have obtained their translation degree (BA and/or MA) or were currently doing their translation coursework. Before participants were recruited for the translation project, they had been provided with project information such as its purpose, tasks and procedures and further explanation had been given wherever they had questions.

A qualitative method was used in this project. Data were collected from a questionnaire and interview in English after the two books were translated. The questionnaire included close-ended questions (multiple choice) and 
open-ended questions (short answer). Eight participants answered the questionnaire and returned their answer sheets, some via email and others in hard copy. Five participants each attended a 20-minute individual interview, which was recorded using a digital recorder in a quiet office. The author provided each interviewee with a list of ten interview questions so that they could have a look at them when they wanted. To keep the participants' identity anonymous, the author labelled them as Participant D, Participant M, Participant Q, Participant T and Participant W. Based on SCT (Vygotsky, 1978), the author used Nvivo 10 as an analytical tool to critically analyse questionnaire and audio-taped interview contents, and categorise relevant and major themes. The following themes emerge from both sources of data.

\section{Enhancing Intercultural Communication Competence through a Team Translation Project Using a Student Engagement Learning Approach}

This section focuses on two points. First, the author looked at the participants' experience appreciating Aboriginal language and culture, and applying various translation techniques. Second, teamwork played an important role in the translation project. We planned learning tasks that meant to utilize team members' knowledge and skills and that could facilitate peer learning, group discussions and seminars. These learning activities occurred on a regular basis and at each group meeting we emphasized translating linguistic and intercultural differences.

\subsection{Appreciating Aboriginal Language and Culture While Applying Translation Techniques}

Culture is a verb characterised by a verbal behaviour (R. Scollon, S. Scollon, \& Jones, 2012) and reflects what members of a cultural group do verbally. Australian Aboriginal cultural heritage mirrors its diverse languages and cultures, and understanding these is essential in translating Aboriginal Sydney and Aboriginal Darwin. There were "around 250 distinct languages at first (significant) European contact in the late eighteen century" (Walsh, 1993, p. 1). However, $64 \%$ of these languages died out following the European invasion due to the racial discrimination policies enforced by the then Australian authorities. For example, "the Retta Dixon Home (Note 5) was initially set up on the Bagot Reserve close to the Reserve hospital. A fence separated the two and the Retta Dixon children were cautioned against going near the 'full bloods' on the Reserve. Those who grew up at Retta Dixon recall they were often hungry and that punishments were harsh. Aboriginal cultural practices and languages were discouraged" (Bauman, 2013, p. 119).

As language and culture are not separable and they permeate each other, the two are looked at in tandem. There are a number of Australian Aboriginal words and expressions in Aboriginal Sydney and Aboriginal Darwin. In translating the two books, we see that Australian Aboriginal languages have contributed to Australian English, particularly its vocabulary. "The term 'Larrakia' refers to a language, an associated stretch of land and water and the people traditionally associated with that land and water" and the Larrakia people are the traditional owners of the land and waters of the Greater Darwin Region" (Bauman, 2013, p. vii). Many things associated with the term are present in the top-end areas, such as HMAS Larrakia (I) (http://www.navy.gov.au/hmas-larrakia-i), HMAS Larrakia (II) (http://www.navy.gov.au/hmas-larrakia-ii), Radio Larrakia (http://www.radiolarrakia.org) and Larrakia TV (http://www.larrakiatv.org.au). Many original Aboriginal words have become part of Australian community life and can be readily found in metropolitan areas. Here is an account by Hinkson (2013, p. xviii).

Despite the force of colonisation and massive industrial development of the past two centuries, much evidence of Aboriginal occupation remains. Some of it has been integrated into the city's contemporary landscape: the names of suburbs such as Cabramatta, Cammeray, Kurnell and Parramatta, to name a few, are derived from words used by Sydney's Aboriginal communities to identify tracts of country. Many street names, parks, and other landmarks also bear the names of Aboriginal people and places. Some major arterial roads, such as King Street, Oxford Street, George Street and Warringah Road are believed to have been constructed on what were originally Aboriginal walking tracks.

In translating these Aboriginal words, we choose to keep their original sounds by using Chinese characters that have similar pronunciation so that its cultural connotations can best remain intact, for example, Larrakia (拉拉琪 雅) and Parramatta (帕拉马塔). This is an accepted technique commonly used in translation and makes it easier for the target readers to match the translations to the original without causing confusion as both Chinese and other language speakers can use the books as bilingual readings. Consequently, we collected and translated as many as 745 person, place, and organization names and kept them in our translation database. Additionally, we found that many everyday Aboriginal words were not so ordinary and had special traditional meanings in the Australian Aboriginal culture. It is well known that the Australian national airline (Note 6) icon is a flying Kangaroo, yet it has an Aboriginal origin and the word has entered English (Walsh, 1993, p.8). Other Aboriginal 
words like "boomerang" and "didgeridoo" have also claimed their legitimate place in English (Leitner \& Sieloff, 1998) and they have become core iconic symbols for Aboriginal life and culture. Evidently, these words are fundamentally and specially related to Aboriginal people's everyday life and cultural experience, and symbolize part of their social practice and cultural behaviour.

The tracks, rocking engravings, drawings and ritual sites found throughout Australia, both in the country (e.g., in western Arnhem Land (Tacon, 1989)) and in the cities (e.g., Darwin and Sydney), are the hard evidence that the Aboroginal people have been the traditional owners of the country. Outstanding rock art and rock engravings are evidenced in many places under protection. In Ku-Ring-Gai Chase National Park, Sydney's North, which was added to the National Heritage List in 2006, we can see extensive evidence of splendid Aboriginal rock art. There are more than 170 rock engraving sites (the Echidna Track, human figures and animals, see further discussion in 5.2.) in the park and shell middens, hand stencils, grinding groves, stone arrangements, burials, and occupation sites can also be found there.

The Aboriginal people lived and travelled in their country and they became familiar with their land. Their experience using various tracks and plants helped them master useful field knowledge and develop many field survival skills like distinguishing wild harmful plants from those that could be used for medical purpose and finding life-saving water holes in the scorching desert. Such knowledge and skills prove to be essential and beneficial in the war fought against the Japanese who invaded Darwin in the World War II. The following is described in Aboriginal Darwin (Bauman, 2013, p. 53).

With the Japanese bombing raids on northern Australia during the Second World War, the threat of invasion became a real possibility. Conventional defense strategies alone could not protect the vast and isolated coastline so the Army co-opted Aboriginal bush skills and knowledge of country to help defend the north. (The underlines are mine)

Here “Aboriginal bush skills and knowledge of country" (原住民的野外生存技能和地域知识) exemplify Aboriginal people's love and duty of care as they patrolled their land, water sources, and forests to protect their country so that they have known every part of it and were able to survive in the wild and on the waters. As "bush skills" have more than what the two words semantically mean, we need "to compensate for translation loss" by "adding a suitable element". Hence “生存” was added to the translation so that "a compensatory translation gain" was achieved (Hatim \& Munday, 2004, p. 31). Another translation strategy is about "semantic fields and lexical sets" (Baker, 1992, p. 18) and “country” is a case in point. It was translated to “地域” instead of “国家” because "country", as a semantic field, has a few lexical sets. “地域” seems to be more specific with reference to the places with which they are familiar while “国家” sounds too abstract or broad.

As reviewed in the literature, an English word can be derogatory and complimentary. The former applies to "the Japanese bombing raids on northern Australia", in which Japanese plane bombing destroyed Darwin and many lives, and committed war crimes, thus "raids" remain derogatory “暴行”. In contrast, the latter applies to the Scottish police's sudden attack. "A Scotland Yard spokesman said Neil Wallis, 60, was taken in for questioning after an early-morning raid on a house in west London - on suspicion of conspiring to intercept communications (Note 7)". Scottish police launched the raid (奇袭) to stop crimes for public safety. Here is another case with the word "interactions" in the following extract.

The sites in this section reveal much about the early interactions between Aboriginal people and the British as the colonists pushed inland from Sydney in search of arable soil. They include stories of Indigenous resistance, and of Governor Lachlan Macquarie's 'civilising' experiments. These foreshadowed later repressive government approaches to the Aboriginal population, including the removal of Aboriginal children from their families. (Hinkson, 2013, p. 117) (The underline is mine)

Here the interactions (冲突事件) between the Aboriginal people and the European settlers could be described as hostile and enemy-like. Such hostile interactions are also derogatory in that the Aboriginal man Pemulwuy was killed and his head was decapitated for his heroic fight against the British invaders after his relationship with them deteriorated (Hinkson, 2013, p. 131). However, their interactions (来往) were friendly on a different occasion and were complimentary (Yang, 2012). The Aboriginal young man Bennelong and Governor Phillip developed such a deep affection for each other that they exchanged name and the latter respected the former's cultural ritual and had his upper front tooth removed during the tooth avulsion ceremony (Hinkson, 2013, p. 28).

Aboriginal Darwin and Aboriginal Sydney were a tourist-friendly guide and provided useful information with many maps and more than 300 images. Additionally, they kept prospective visitors informed of the social and cultural practices of the Aboriginal communities. For example, neither men nor women were permitted to get 
close to some of the sites where the community members thought there was a supernatural power bestowed by their ancestors. This can be seen in the following.

It is commonly accepted that engravings have religious/sacred significance. Within an Aboriginal worldview, the original creators of these engravings were ancestral beings. The engravings were made in the time before human beings occupied the earth (often referred to as the Dreamtime, the Dreaming or the Ancestral Past), the period in which ancestral beings roamed the continent, giving it form and filling it with life. (Hinkson, 2013, p. 63) (The underlines are mine)

One of the significant Aboriginal people's activities was the 'Dreamtime' (梦幻时光) or the 'Dreaming' (梦幻). It sounds ordinary to non-Aboriginal speakers, but has something special in Australian Aboriginal culture. It represents "the past, present and future" and "reaches back to the activities of mythological ancestral beings as they travelled the country giving meaning to features in the landscape like rocks, rivers and mountains" (Bauman, 2013, p. xii). These activities become meaningful and important for the Aboriginal people as it is their responsibility to inspect their country and make it known to the world that their ancestors and off-springs have been living on this land, and protect it to the best of their ability. It is only with the background information in mind of Aboriginal Dreaming (梦幻) or Dreamtime (梦幻时光) (Tacon, 1989) that Chinese translation makes sense of the original cultural meaning.

Each culture has its own established social practice and community values that make it unique and spectacular for its long history and resistance to outside temptation. Sometimes, non-Aboriginal tourists may feel curious and puzzled about the Aboriginal traditional society which has different communication style from the Anglo-Saxon Australian community. While longer silence is rarely practiced in white Australian conversation, it is socially common and widely accepted in Australian Aboriginal talk-in-interaction (Mushin \& Gardner, 2009). More information and meaning are presented in the context of nonverbal behaviour rather than verbal counterpart. What is nonverbally presented is more meaningfully communicated through such representation as rocking engravings, stone arrangements, ritual dancing and social ceremonies, only to mention a few.

The only surviving Aboriginal account of Sydney rock engravings comes from Queen Gooseberry, wife of Bungaree. Sometime in the 1840s, Gooseberry, who was a noted personality of Sydney, was asked to show and explain engraving sites near Sydney to a group of Europeans. At first she was reluctant, saying that such places were 'forbidden ground' and that she must not visit them. Later she was persuaded to take a party of people to several sites in the vicinity of North Head. Gooseberry was reported as saying that she had been told by her father that 'black fellow made them long ago' and that Aboriginal people visited the sites on special occasions, when dances and ceremonies took place. At other times they stayed away because 'too much debble [powerful spirit beings] walk about there'.

Although some Aboriginal sites have been open to the public, others remain inaccessible due to their religious beliefs and cultural practices. It is generally understood in the Aboriginal community that many sites, where their ancestors were buried, are not open, particularly to outsiders, so that they remain undisturbed and rest in peace. This is one of the ways in which Aboriginal people show great respect for their ancestors and they stick to the established community rituals. Similar stories of supernatural power can also read from the following description of Dariba Nungalinya (Old Man Rock) (Bauman, 2013, pp. 128-129).

Dariba Nungalinya is a long, low reef of rocks which can be seen at low tide from Casuarina Beach. It is the embodiment of a powerful Larrakia ancestor who is said to protect Larrakia people and is commonly referred to as 'Old Man Rock'. Dariba is Larrakia for 'old man' and is a term of respect. Nungalinya is the name of the Larrakia ancestral being who lies in the water off Casuarina Beach. There are several versions of the Dariba Nungalinya Dreaming story but the information is not generally available to the public.

The importance and power of Dariba Nungalinya as a sentient being is recognized by many Aboriginal people and others in Darwin. Any disturbance of the rock is dangerous and is likely to lead to natural disasters. For example, Cyclone Tracy is attributed to the wrath of Dariba Nungalinya. It is critical that the rocks are not touched or disturbed and the 'old man' is treated with respect and compassion. The Larrakia are vigilant to ensure Dariba Nungalinya is treated appropriately.

The stories are told to inform visitors of Aboriginal cultural codes and tourists are reminded that the Aboriginal social practices are to be respected. Visitors are not allowed to access some places (e.g. ritual or burial sites) without a permit because the Aboriginal people consider them sacred. Respecting people's privacy as social 
practice is an important matter. Tourists are advised to visit the Aboriginal homes or some groups of Aboriginal people only when they are invited or have got the individual's consent. As many Aboriginal sites have remained unknown to the outside world, some cultural differences, sometimes caused by linguistic differences, pose challenges in translating Aboriginal language (Goddard, 1991). Despite this, using simple words and sentences to explicate the indirect and hidden meaning of the Aboriginal language may help make it translatable (Hatim \& Munday, 2004; Wierzbicka, 2013). Our team translation experience shows that intercultural translation is challenging but interesting and educational as we use all resources available to make the project engaging along the way.

\subsection{Enhancing Intercultural Communication Competence through a Student Engagement Learning Approach}

As reviewed in the literature, intercultural communication competence entails cross-linguistic competence and intercultural competence, including relevant knowledge base and skills. Our translation project provides an opportunity for participants to enhance their intercultural competence through translating two English books to Chinese. Kiraly (2000) writes that social constructivist approach is a useful and scaffolding method fit for translator education and can be used to guide translators to combine knowledge, skills and theories with real practice through classroom case studies, peer learning activities, translation projects, and seminar talks. Enhancing students' intercultural communication competence through the translation project is evidenced in participants' survey feedback and interview results. They will be discussed below with reference to various purpose-built learning activities.

\subsubsection{Individual Attempt and Critical Reflection}

One useful strategy each student participant used in translating the books was conducting online enquiry and library research. Participant D recalled that she used Internet, reference books and magazines to broaden her knowledge needed for the translation project. She read another English book "The Secret River" written by Kate Grenville (http://kategrenville.com/The_Secret_River) in 2005. It was about Aboriginal people's interaction, both friendly and hostile, with the European settlers sent to New South Wales as convicts. Apparently her extensive reading about Aboriginal people's determination not to give away their land to the European invaders helped understand their persistent fight for basic human rights and their claim as traditional owners of the country. She also recalled that the more she read, the more she became interested in the story mysteries concerning the Aboriginal history and culture. Just as Mr Russel Taylor, Principal of the Australian Institute of Aboriginal and Torres Strait Island Studies (AIATSIS), wrote in his foreword to Aboriginal Darwin (Bauman, 2013) and Aboriginal Sydney (Hinkson, 2013) that he "was immersed in the dominant 'whitefella' culture, the built environment and their representations of history, I was very conscious of the apparent absence of any 'blackfella' history, culture and presence". Such absence resulted in little knowledge about the first traditional owner of Australia on the part of people living in other places of the world. This was exactly what was conspired by the former governments in the Australian history since 1788 as can be seen in the following.

Over the next 150 years, further disruption of communities and forced movement of Aboriginal people occurred across New South Wales, as successive governments tried to deal with what they saw as 'the Aboriginal problem'. Initially white authorities thought that Aboriginal people were destined to 'die out', and from the late 1880s a policy based ostensibly on their 'protection' was introduced. The centrepiece of this policy was the establishment of segregated Aboriginal reserves. From the 1930s, once it had become clear that such predictions were false, and that rather than dying out the Aboriginal population was in fact growing, a new policy of 'assimilation' was introduced, geared towards the absorption of Aboriginal people into mainstream society. (Hinkson, 2013, p. xxvi)

Evidently there was strong racial discrimination against the Aboriginal people and an institutional conspiracy, including physical, psychological and emotional harms done to the Stolen Generations (Augoustinos, LeCouteur, \& Soyland, 2002; Petchkovsky \& San Roque, 2002; Young, 2009), was plotted to eliminate them, their history, and culture. Although they were disadvantaged, the Aboriginal people had the inspiration and strength from their ancestors that helped them survive. Their presence emerged after being diminished for so long. Its history mysteries and cultural heritage have been so glorious and brilliant that they have come to be recognised in Australia and around the world. On behalf of Australian federal government, the former Prime Minister Kevin Rudd, while he was in office, made a national apology to all Australia's Indigenous Peoples on 13 Feb 2008 though his predecessors had refused to do so.

All translation participants have come to know that the Aboriginal people have a long history and that their cultural heritage dates back to 50,000 years ago. They are sure that there are more history mysteries in the books. 
Indeed, they find some questions are addressed through library research or via the Internet (which often proves to be very informative and helpful because of many links to additional sources of information) while others are brought forward for group discussion.

\subsubsection{Group Discussion and Peer Learning}

Group discussion is a useful platform where every individual participant raises their questions, discussing the interesting topics and giving their input. Days before the group meets, discussion questions are circulated so that every participant has sufficient time to have a look at the relevant book sections, consults resources available and prepares for each regularly scheduled group discussion session.

Group discussion was commonly used for maximising learning opportunity and effectiveness in many education environments like primary/secondary schools, education centres and university classrooms. It was regularly used in our project. Participant $\mathrm{T}$ owes his better understanding of some difficult points in translating the book sections to group discussion which provides an opportunity for team members to communicate with one another. This learning activity also enables them to talk about the topics with interest in the questions under discussion as they all have done some research, and worked on the best answer to the question. It is argued that peer talking can motivate fellow students to engage in the discussion, explore, analyse subject matters with strong interest (Tan, 2003) and group discussion can help students improve meaningful communication skills, negotiate meaning and produce better written language output (Malmqvist, 2005). Participant T adds that group discussion helps all members compare notes, clarify their points, and creates an environment in which learning autonomy occurs. As Ho (2011) points out, group discussion focuses on developing students' receptive skills, critical thinking, academic socialisation and teamwork, encourages cooperative learning and accommodates individual learning needs. These benefits are reflected in our team members' experience supporting each other with team strength and getting fully prepared for the group discussion relevant to their translation tasks.

Group discussion can help translation debates effectively. One of the debates centres on the translation of the two book titles Aboriginal Sydney: A Guide to Important Places of the Past and Present (2010) and Aboriginal Darwin: A Guide to Exploring Important Sites of the Past \& Present (2006). Some team members propose that as few words as possible be used in translating a book title while keeping the original idea whereas others suggest that additional words be added to the translated title. Both sides were given an opportunity to state reasons to support their arguments. The title debate is so heated that a third opinion (that of an independent translator) is sought. Finally, it is agreed that 悉尼原住民:今昔重要遗址指南 and 达尔文原住民:探索今昔重 要遗址指南 are appropriate Chinese translations. There are two reasons for this version. One is that the above Chinese translations are closer to the original, achieving fidelity which is an essential translation principle (Hatim \& Munday, 2004), and the other is that it is smart to keep book titles concise to retain readers' attention.

Group discussion provides every team member an opportunity to reflect on and discuss their own translated work and others' as well, thus helping them learn through reflective learning. Participant W's experience using library and the Internet resources while translating her book sections shows there are insufficient resources available about translating culture-loaded Aboriginal texts. Since translating cultural differences is the most challenging task of all but crucial and educational, we need interactions with experts in Aboriginal studies who are consulted on the cultural information. We communicate with them and ask questions about the Aboriginal language and culture, and the cultural information they provided is very helpful. Furthermore, all project participants met with Aboriginal studies experts and discussed the culture-loaded languages and complex cultural heritage at seminars.

\subsubsection{Seminars as an Extension Learning Activity}

Seminars are an important and effective channel through which a roundtable discussion is organised for all participants and Aboriginal studies experts to interact with one aother. The latter include Aboriginal Studies Press director who is committed to building and maintaining cooperative working relationship with new and established writers in the field of Indigenous Studies and a university lecturer in Indigenous Studies. Some days before the seminar take place, we send them a list of Aboriginal culture-related questions.

The project participants' feedback on what they learn about the Aboriginal culture at this seminar is very positive. Participant Q comments that she is impressed by the rich cultural information provided and discussed at the seminar. For example, the contemporary Aboriginal communities and the non-Aboriginal communities value the Blacktown Native Institution site where intercultural communication has occurred among many cultural groups. In the minds of the Aboriginal people, this institution symbolises "dispossession and child removal" and "has the potential to reveal evidence, which may not be available from other sources, about the lives of the children who lived at the school and the customs and management of the earliest Aboriginal school in the colony" 
(http://www.environment.nsw.gov.au/heritageapp/ViewHeritageItemDetails.aspx?ID=5051312). Such institution was established by the colonists to "civilise" the Aboriginal children who "were captured by British soldiers during punitive expeditions ordered by Macquarie in May and June 1816" (Hinkson, 2013, p. 135). Those Aboriginal children who were removed from their families became known as the Stolen Generation (Augoustinos et al., 2002; Petchkovsky \& San Roque, 2002; Young, 2009). Together with her peers, Participant $\mathrm{Q}$ became so interested in the Aboriginal history and culture that she wants to visit the Aboriginal sites and see ritual ceremonies with her own eyes.

It is through the seminar meeting and discussion with the experts in the Aboriginal studies that all participants realise that "institution" in this context, along with its associated words, has different cultural connotation than they have first thought. In its historical context, "institution" represents imposition of the colonists' will on the Aboriginal people to make them "civilised" and domesticated, spiritually detached from their own tradition, language, cultural values, and social practices. Such conspiracy can be seen in the following transcripts titled "Northern Ireland Abuse Commission Sends Investigators to Australia".

GORDON BROWN, THEN BRITISH PRIME MINISTER (Feb. 2010): We are truly sorry. They were let down. We are sorry they were allowed to be sent away at the time they were most vulnerable. KAREN PERCY: Britain and Australia have made public apologies to those who were institutionalised, but have offered no compensation.

(Adapted from http://www.abc.net.au/lateline/content/2013/s3873913.htm)

Apparently, words like "institution" and "institutionalised" have, in this context, strong racial discrimination and segregation against the Aboriginal people who were belittled as a genetically inferior group, and hence they were treated unequally, exploited physically, abused psychologically and emotionally. In this sense, "institution" is cross-culturally different from what it semantically means in Chinese context. Understanding such a cultural difference helps increase student translators' intercultural sensitivity.

At the seminar, we also watch a 51-minute online video episode "Who do you think you are?" (http://www.sbs.com.au/ondemand/video/11731011530) and learn what has happened in Catherine Freeman's Aboriginal family history. Following Cathy's travel and search for her family roots, everyone is excited to discover that the Australian Olympic champion has Chinese heritage a few generations back-Cathy's great-grandfather Tommy Ah Sam (a Chinese man married with an Aboriginal woman Maggie Croydom). Evidently, Chinese immigrants interculturally have interacted with the Aboriginal people in Australian history, had successful intercultural marriage, fought vigorously for their rights, and contributed greatly to Australia today.

\section{Conclusion}

This paper focuses on the various learning activities we design to engage Chinese student translators in the ACC-funded translation project on the Aboriginal history and culture and to develop their linguistic awareness and intercultural communication competence while putting translation theory into practice. These activities include individual translator's individual attempts and reflections as well as their active use of various resources available, such as library materials and the Internet information. It was through each individual's work on different book sections that they start to pick up questions of either linguistic ambiguities or cross-cultural misunderstanding (Yang, 2011a). They are motivated to find answers to these questions and further reflect on the materials. When some of them remain too difficult to solve individually, they are raised at the group discussion sessions which are scheduled on a regular basis (Malmqvist, 2005). This create an opportunity for all participants to meet, listening to their fellow students' viewpoints and findings, and giving their own input after purposeful research and critical analysis, with all participants changing from talking little to speaking more (Jones, 1999). Furthermore, seminars gave all participants a chance to communicate with Aboriginal researchers and experts in the Aboriginal studies. Question-and-answer exchanges motivated all parties to think more deeply and critically. In spite of these learning activities, we also came to realise that additional learning activities like visiting the Aboriginal sites or meeting with Aboriginal residents, would be a plus adding to our knowledge and understanding of the subject matter under discussion. This can be considered in our future translation project.

The general outcome of this translation project is that all participants have enhanced their intercultural communication competence through understanding the Aboriginal culture and appreciating their traditional practices by the time when they finish translating the two books within one-year timeframe. The two English-Chinese bilingual books can help many more Chinese speakers, old and young, read and discover the most important part of the Aboriginal history and culture which has been made absent for long. 
Our students' experience with this meaningful and interaction-based translation project shows that engaged learning approach has three thought-provoking pedagogical implications for university translation teaching and learning. First, student engagement learning approach encourages students to become more engaged in the undertaking while developing various study skills like library research and reflective learning which are beneficial to pre-service and in-service professionals (Parkison, 2009). As they go, their motivation to find the answer to the puzzling questions and to have the best translation done becomes stronger, and this exploratory learning can take place through teamwork and collaboration. Second, students can effectively improve their intercultural communication competence through translating materials that focus on diverse cultures (Davies, 2012). They not only improve their translation skills, but also gain authentic intercultural knowledge and sharpen their intercultural sensitivity (Kayyal, 2004; Wu, 2010). It is worth using role plays with students translating/interpreting of culture-loaded texts as an innovative method to train and evaluate pre-service and in-service translators/interpreters (Elorza, 2008). Finally, students can become comfortable to achieve peer learning through communicating with each other, feel interested in finding research results and presenting their input at discussion sessions, and participate in team collaboration while engaged in team-based tasks and projects (Yang, 2013). This in turn enables them to learn various learning skills and perform better in their university coursework, particularly in individual and team presentation. In the long term, the student engagement in learning approach will prepare university students well for their future career development.

Though the project-based translation is beneficial and successful in implementing in-context teaching and learning translation theory and skills, and student engaged learning activities, we have realised that highly committed team members, well-organised project management skills, and various institutional and administrative support are indispensable.

\section{Acknowledgments}

As team leader of this translation project, the author acknowledges that "Understanding Australian Aboriginal Culture through Translation" was proudly funded by The Commonwealth through the Australia-China Council of the Department of Foreign Affairs and Trade, together with UWS School of Humanities and Communication Arts. Thanks go to all participants who have contributed to the successful teamwork on Aboriginal Darwin and Aboriginal Sydney and those that participated in this research project.

\section{References}

Adab, B. (2000). Cross-cultural assumptions in the translation of advertising-how realistic are they ? Across Languages and Cultures, 1(2), 193-207.

Alptekin, C. (2002). Towards intercultural communicative competence in elt. ELT Journal, 56(1), 57-64. http://dx.doi.org/10.1093/elt/56.1.57

Augoustinos, M., LeCouteur, A., \& Soyland, A. J. (2002). Self-sufficient arguments in political rhetoric: Constructing reconciliation and apologizing to the stolen generations. Discourse \& Society, 13(1), 105-142.

Baker, M. (1992). In other words: A coursebook on translation. New York: Routledge.

Bauman, T. (2013). Aboriginal darwin: A guide to exploring important sites of the past \& present (达尔文原住 民: 探索今昔重要遗址指南), translated by 西悉尼大学澳大利亚原住民历史文化翻译课题小组. Canberra (坎培拉): Aboriginal Studies Press (原住民研究出版社).

Cao, Y., \& Philp, J. (2006). Interactional context and willingness to communicate: A comparison of behavior in whole class, group and dyadic interaction. System, 34(4), 480-493. http://dx.doi.org/10.1016/j.system.2006.05.002

Chu, P.-Y. (2007). How students react to the power and responsibility of being decision makers in their own learning. Language Teaching Research, 11(2), 225-241. http://dx.doi.org/10.1177/136216880607074613

Cunico, S. (2005). Teaching language and intercultural competence through drama: Some suggestions for a $\begin{array}{lllll}\text { neglected } & \text { resource. Language Learning }\end{array}$ http://dx.doi.org/10.1080/09571730585200051

Davies, E. E. (2012). Translation and intercultural communication: Bridges and barriers. In C. B. Paulston, S. F. Kiesling, \& E. S. Rangel (Eds.), The handbook of intercultural discourse and communication (pp. 367-388). Malden, MA: John Wiley \& Sons, Ltd.

Diochon, M. C., \& Cameron, A. F. (2001). Technology-based interactive learning: Designing an international student research project. Active Learning in Higher Education, 2(2), 114-127. http://dx.doi.org/10.1177/1469787401002002003 
Elorza, I. (2008). Promoting intercultural competence in the FL/SL classroom: Translations as sources of data. Language and Intercultural Communication, 8(4), 261-277. http://dx.doi.org/10.1080/14708470802303090

Goddard, C. (1991). Testing the translatability of semantic primitives into an Australian Aboriginal language. Anthropological Linguistics, 33(1), 31-56.

Grim, F. (2010). Giving authentic opportunities to second language learners: A look at a French service-learning project. Foreign Language Annals, 43(4), 605-623. http://dx.doi.org/10.1111/j.1944-9720.2010.01104.x

Hatim, B., \& Munday, J. (2004). Translation: An advanced resource book. New York: Routledge.

Hinkson, M. (2013). Aboriginal Sydney: A guide to important places of the past and present (悉尼原住民:今昔 重要地点指南), translated by 西悉尼大学澳大利亚原住民历史文化翻译课题小组. Canberra (堪培拉): Aboriginal Studies Press (原住民研究出版社).

Ho, M.-C. (2011). Academic discourse socialization through small-group discussions. System, 39(4), 437-450. http://dx.doi.org/10.1016/j.system.2011.10.015

House, J. (2009). Moving across languages and cultures in translation as intercultural communication. In K. Bührig, J. House, \& J. D. ten Thije (Eds.), Translation action and intercultural communication (pp. 7-39). Manchster, UK: St Jerome Publishing.

Jones, J. F. (1999). From silence to talk: Cross-cultural ideas on students participation in academic group discussion. English for Specific Purposes, 18(3), 243-259.

Kayyal, M. (2004). Intercultural relations between Arabs and Israeli Jews as reflected in Arabic translations of modern Hebrew literature. Target, 16(1), 53-68. http://dx.doi.org/10.1075/target.16.1.04kay

Kim, Y. Y. (2003). Adapting to an unfamiliar culture: An interdisciplinary overview. In W. B. Gudykunst (Ed.), Cross-cultural and intercultural communication (pp. 243-258). Thousand Oaks, CA: Sage Publications.

Kiraly, D. C. (2000). A social constructivist approach to translator education: Empowerment from theory to practice. Manchester, UK: St Jerome.

Leitner, G., \& Sieloff, I. (1998). Aboriginal words and concepts in Australian English. World Englishes, 17(2), 153-169. http://dx.doi.org/10.1111/1467-971X.00089

Little, D. (2009). Language learner autonomy and the European language portfolio: Two L2 English examples. Language Teaching, 42(2), 222-233. http://dx.doi.org/10.1017/S0261444808005636

Malmqvist, A. (2005). How does group discussion in reconstruction tasks affect written language output? Language Awareness, 14(2\&3), 128-141. http://dx.doi.org/10.1080/09658410508668829

Mughan, T. (1999). Intercultural competence for foreign languages students in higher education. Language Learning Journal, 20(1), 59-65. http://dx.doi.org/10.1080/09571739985200281

Muńoz-Calvo, M. (2010). Introduction: Translation and cross-cultural communication. In M. Muñoz-Calvo, \& C. Buesa-Gómez (Eds.), Translation and cultural identity: Selected essays on translation and cross-cultural communication (pp. 1-12). Newcastle upon Tyne: Cambridge Scholars Publishing.

Mushin, I., \& Gardner, R. (2009). Silence is talk: Conversational silence in Australian Aboriginal $\begin{array}{llll}\text { talk-in-interaction. Journal of 2033-2052. } & \text { Pragmatics, }\end{array}$ http://dx.doi.org/10.1016/j.pragma.2008.11.004

Parkison, P. T. (2009). Field-based preservice teacher research: Facilitating reflective professional practice. Teaching and Teacher Education, 25(6), 798-804. http://dx.doi.org/10.1016/j.tate.2008.11.017

Petchkovsky, L., \& San Roque, C. (2002). Tjunguwiyanytja, attacks on linking: Forced separation and its psychiatric sequelae in Australia's 'Stolen Generations'. Transcultural Psychiatry, 39(3), 345-366. http://dx.doi.org/10.1177/136346150203900304

Pym, A. (2004). Propositions on cross-cultural communication and translation. Target, 16(1), 1-28. http://dx.doi.org/10.1075/target.16.1.02pym

Scollon, R., Scollon, S. W., \& Jones, R. H. (2012). Intercultural communication: A discourse approach (3rd ed.). Malden, MA: Wiley-Blackwell.

Sellnow, D. D., \& Ahlfeldt, S. L. (2005). Fostering critical thinking and teamwork skills via a problem-based learning (PBL) approach to public speaking fundamentals. Communication Teacher, 19(1), 33-38. http://dx.doi.org/10.1080/1740462042000339258 
Sorby, S. (2008). Translating news from English to Chinese: Complimentary and derogatory language usage. Babel, 54(1), 19-35. http://dx.doi.org/10.1075/babel.54.1.03sor

Starke-Meyerring, D. (2005). Meeting the challenges of globalization: A framework for global literacies in professional communication programs. Journal of Business and Technical Communication, 19(4), 468-499. http://dx.doi.org/10.1177/1050651905278033

Tacon, P. S. C. (1989). From the "Dreamtime" to the present: The changing role of Aboroginal rock paintings in western Arnhem Land, Australia. The Canadian Journal of Native Studies, IX(2), 317-339.

Tan, B. T. (2003). Does talking with peers help learning? The role of expertise and talk in convergent group discussion tasks. Journal of English for Academic Purposes, 2(1), 53-66. http://dx.doi.org/10.1016/S1475-1585(02)00033-4

Turner, Y. (2009). "Knowing me, knowing you," is there nothing we can do?: Pedagogic challenges in using group work to create an intercultural learning space. Journal of Studies in International Education, 13(2), 240-255. http://dx.doi.org/10.1177/1028315308329789

Vygotsky, L. S. (1978). Mind in society: The development of higher psychological processes. Cambridge: Harvard University Press.

Walsh, M. (1993). Languages and their status in Aboriginal Australia. In M. Walsh, \& C. Yallop (Eds.), Language and culture in Aboriginal Australia (pp. 1-14). Canberra: Aboriginal Studies Press.

Wierzbicka, A. (2002). Australian cultural scripts—bloody revisited. Journal of Pragmatics, 34(9), 1167-1209. http://dx.doi.org/10.1016/S0378-2166(01)00023-6

Wierzbicka, A. (2013). Translatability and the scripting of other peoples' souls. The Australian Journal of Anthropology, 24(1), 1-21. http://dx.doi.org/10.1111/taja.12018

Woodward-Smith, E., \& Eynullaeva, E. (2009). A cross-cultural study of the translation and adaptation of advertisements for beauty products. Perspectives: Studies in Translatology, 17(2), 121-136. http://dx.doi.org/10.1080/09076760902999225

Wu, G. (2010). Translating differences - a hybrid model for translation training. Translation \& Interpreting, 2(1), 24-37.

Yang, P. (2011a). Developing cross-cultural communication competence through translation. In A. Arnall \& U. Ozolins (Eds.), Proceedings of the "Synergise!" Biennial National Conference of the Australian Institute of Interpreters and Translators: AUSIT 2010 (pp. 48-65). Newcastle upon Tyne, UK: Cambridge Scholars Publishing.

Yang, P. (2011b). Knowledge is power: Communicating across cultural borders with sensitivity to Others. Paper presented at the Knowledge/Culture/Social Change: International Conference CCR, UWS. 7-9 November 2011, University of Western Sydney, Sydney, Australia, .

Yang, P. (2013). Two heads are better than one: Team teaching in TESOL internship. Studies About Languages, 23, 113-125. http://dx.doi.org/10.5755/j01.sal.0.23.4995

Young, R. (2009). The stolen generation. Psychotherapy in Australia, 16(1), 59.

杨平. (2012). 英汉翻译中的裹贬词语选择 (complimentary and derogatory wordings in English-Chinese translation). 上海翻译 (Shanghai Journal of Translators), 27(4), 28-30.

\section{Notes}

Note 1. Banham, C. (2007). Terrorists have ambitions of empire, warns Cheney. The Sydney Morning Herald, 24-25 February, 2007, p. 1 and 7.

Note 2. Ferguson, S. (2007). Boundless ambition. The Daily Telegraph, 9 November, 2007, p. 60.

Note 3. Now the bloody Yanks are offended, see http://www.smh.com.au/news/national/now-the-bloody-yanksare-offended/2006/03/23/1143083882873.html

Note 4. Smith, M. (2006). No bloody half beer in Canada. The Daily Telegraph, Thursday 23 March 2006, p. 15.

Note 5. Since 2010, a series of articles have been published in The Australian about Retta Dixon Home abuse of Aboriginal children.

Note 6. According to a recent report, "the 93-year-old Qantas commands a prominent place in the Australian 
psyche, in the nation's global image of itself. The name of the so-called Flying Kangaroo is an acronym for 'Queensland and Northern Territory Aerial Services', and the words 'Spirit of Australia" are painted on each of its aircraft. (http://www.smh.com.au/business/a-downgrade-for-qantas-a-lesson-for-australias-economy-2014 0112-30opq.html\#ixzz2qpQ1dhrF)

Note 7. Dick, Tim (2011). Ninth arrest in hacking scandal and Gillard has some media advice. The Sydney Morning Herald. 15 July 2011, p. 1.

\section{Copyrights}

Copyright for this article is retained by the author(s), with first publication rights granted to the journal.

This is an open-access article distributed under the terms and conditions of the Creative Commons Attribution license (http://creativecommons.org/licenses/by/3.0/). 